\title{
HISTORY OF TRICHINELLOSIS SURVEILLANCE
}

\author{
BLANCOU J.*
}

\section{Summary :}

The origin of trichinellosis, which existed in ancient times as testified by the discovery of parasite larvae on an Egyptian mummy, unfolded in several stages: discovery of encapsulated larvae (in the 1820s), identification and scientific description of these larvae (Paget \& Owen, 1835), followed by experimental infestations of animals (dogs, pigs, rabbits, mice) or of humans as from 1850

The main occurrences of trichinellosis were followed with particular attention in Europe (Germany, Denmark, France, etc.) and in the United States of America at the end of the XIXth century. They affected numerous domestic animal species (pigs, horses, etc.) or wildlife and humans. Germany paid the heaviest toll with regard to the disease in humans, between 1860 and 1880 , with several thousands of patients and more than 500 deaths.

Different trichinellosis surveillance systems were set up in the relevant countries in the 1860s. In humans, this surveillance was carried out on affected living patients by a biopsy of the biceps muscles and subsequently by an analysis of eosinophilia (1895). In animals, surveillance was for a long time solely based on postmortem examination of the muscles of the affected animals. This method was used for the first time in 1863 in Germany, and from the 1890s, on several hundreds of thousands of pigs in Europe or in the United States of America.

KEY WORDS : trichinellosis, history, epidemiology, surveillance.

\section{INTRODUCTION}

C ases of infestation by Trichinella worms go back, very probably, to very ancient times. Indeed, in 1974 larvae of this parasite were discovered in the intercostal muscles of the corpse of an Egyptian mummified around 1200 B.C. (Campbell, 1983).

However, it was not until the 19th century that the larvae of the parasite, and then its adult forms, were observed, identified and recognised as the source of the morbidity or mortality of their hosts. These various discoveries were made in several stages by European doctors and biologists ${ }^{1}$.

\footnotetext{
* Director General, Office International des Epizooties, 12, rue de Prony, 75017 Paris, France.

Tel.: 33 (0)1 44151888 - Fax: 33 (0)1 42670987

E-mail:oie@oie.int

${ }^{1}$ A large part of the information concerning the history of this discovery was drawn from the excellent chapter by W.C. Campbell Historical Introduction (Campbell, 1983).
}

\section{THE DISCOVERY OF ENCAPSULATED LARVAE}

In 1821, Friedreich Tiedemann observed "stony concretions" in the muscles of a human cadaver and had them chemically analysed by Gmelin, but without observing them under a microscope. According to Campbell, these concretions were very probably encapsulated Trichinella larvae, although this was never proven (Campbell, 1983).

In 1828, Peacock was the first to find and collect small "bony points" that were later recognised to be the encapsulated larvae of the parasite. These lesions were found in the larynx muscles of a dead patient at Guy's Hospital in London. Unfortunately, Peacock did not pursue the matter before the observation of these samples and did not write about his discovery in any scientific publication. The sample analysed therefore figured, without any precise description, in the catalogue of the Hodgkin Museum until 1858, when an additional observation led to the identification of the contents of the "bony points" and a description of their nature: the encapsulated larvae of a worm, described by Owen in 1835 (see below).

\section{IDENTIFICATION OF THE ENCAPSULATED LARVAE}

Identification of the larvae was the fruit of collaboration between two Englishmen, James Paget and Richard Owen. The former was a first-year medical student when, on 2 February 1835, he discovered "specks" in the muscles of the corpse of an Italian by the name of Paolo Bianchi, who died and was autopsied at St Bartholomew's Hospital in London (Campbell, 1979). He examined them under the microscope and drew, for the first time, an encapsulated larva, then told the hospital students' club about his discovery. He entrusted the samples that he had taken to Richard Owen, who published the description of the parasite (which he named Trichina spiralis) stating that Paget had first discovered the parasite.

Nevertheless, there is still some small controversy over who was the first to observe the phenomenon, because another author, John Hilton, had also observed "specks" in 1833 during an anatomical dissection. He did not observe the encapsulated larva, but he did 
nevertheless try to infect rabbits by subcutaneous inoculation of the material he had gathered. Although this attempt to inoculate was doomed to failure, it proved that Hilton also suspected the existence of a transmissible agent in his samples, which he wrongly believed to be the larvae of cestodes (Cysticercus).

\section{EXPERIMENTAL INFESTATION AND DISCOVERY OF THE PARASITIC CYCLE}

The first experimental attempt of infestation ${ }^{2}$ was thus carried out by Hilton, who had not thought of using the oral route (see above).

It was Herbst, in 1850 , who was the first to succeed in transmitting trichinellosis to three puppies that he had fed on the muscles of a badger in which he had observed the larvae of the parasite.

In 1857 , Leuckart successfully infected laboratory mice and in 1859, Virchow succeeded in infecting a dog, but these two authors were late in their conclusions due to confusion between Trichina and Trichuris, based on the theory advanced by Küchenmeister in 1855 on the identity of these two worms.

It was finally Zenker who definitively clarified the situation. In January 1860, he observed living and very mobile larvae in a muscular sample taken from a young woman who had recently died following a parasitic infestation. During a veritable epidemiological investigation, he found the adult forms of the worm in the intestine of the young woman and traced the source of this infestation: the consumption of pork carrying the parasite. He sent these muscular samples to Leuckart and Virchow, who went on to successfully infect a rabbit, a dog and a pig. The latter should already have been under suspicion when in 1846 Leidy discovered the larvae in a slice of pork served to him at dinner. However, the German authors, in particular Leuckart, decided to direct their research at dogs. Nevertheless, it was these German authors who finally described the complete cycle of Trichinella spiralis $^{3}$, which begins with the coupling of adult worms in the intestine of the host, then the birth of the larvae from fecund females, followed by the migration of the larvae via the lymphatic system to the muscles of the host.

In this assay we describe the different episodes of trichinellosis observed in animals and humans from the 19th century onwards, then the various surveillance

\footnotetext{
${ }^{2}$ There are also several historic cases of voluntary experimental selfinfestation by humans, at the end of the 19th century. In Chicago, Belfield ingested 12 trichinella larvae, with no subsequent harmful effects; in Germany, two sceptic men consumed voluntarily contaminated sausages and one of them died (Campbell, 1983).

${ }^{3}$ The name Trichinella was substituted for Trichina, in 1895, by Raillet, when this author discovered that the generic name Trichina had already been allocated, in 1830, to a dipteran (Blancou, 2000).
}

systems set up to identify sick animals and to eliminate them from the food chain.

\section{MAIN EPISODES OF TRICHINELLOSIS}

T should be remembered that the majority of mammals are susceptible to infection by $T$. spiralis. It is 1 difficult, under these conditions, to obtain precise reports on an infection that can affect so many species, and the best-documented cases of trichinellosis are therefore those affecting humans.

\section{IN ANIMALS}

Historically, the first species recognised as naturally infested was the badger (Herbst, 1850) but, very rapidly, the susceptibility of many other species was demonstrated in all regions of the globe. The bestdocumented cases have been reported in the following species:

\section{- Pigs}

The disease was reported as enzootic in these animals around the end of the 19th century, especially in Europe. In 1885 , the proportion of pigs recognised as infected in the abattoir was 55 per 100,000 in Germany, but a high number of infected subjects was also reported in other European countries: Denmark (50 per 100,000 in 1914), Spain, Holland, Russia, Sweden, etc. (Brumpt, 1949; Martel et al., 1906).

In the United States of America, there was a widespread infestation: 930 per 100,000 of pigs imported to Hamburg at the end of the century were recognised as infected (Brumpt, 1949). In Chile, in 1898, 42 pigs were found to be infected out of 19,052 examined (equivalent to 230 per 100,000 ).

- Horses

The first cases of trichinellosis in humans, which without doubt came from the consumption of horse meat, date back to 1975. Since this date, 3,000 cases in humans have been reported in France and in Italy, leading to the death of five people. The meat had been imported variously from North America (Canada, United States of America and Mexico) and Eastern Europe (Touratier et al., 1999).

\section{- Other species}

At the end of the 19th century, investigations were carried out into the prevalence of the infestation of sewer rats by $T$. spiralis: these animals were recognised as being infected by the parasite in the proportion of 7 per 100 in France, eight per 100 in Germany and 30 per 100 in the abattoirs of Boston in the United States of America (Martel et al., 1906).

Polar bears are also heavily infected by the parasites. According to Campbell, the death of three Swedish 


\begin{tabular}{|c|c|c|c|c|c|}
\hline Period & Territory & Infected product & Origin of the product & $\begin{array}{l}\text { Number of sick } \\
\text { and/or deaths }\end{array}$ & $\begin{array}{l}\text { Bibliographic } \\
\text { references }\end{array}$ \\
\hline $1860-1880$ & Germany & Pork & Local & $\begin{array}{l}\text { Several thousand } \\
\text { sick and at least } \\
500 \text { dead }\end{array}$ & (Campbell,1983) \\
\hline 1866-1904 & Denmark & Pork & Local & 47 sick and 9 dead & (Martel et al., 1906) \\
\hline 1878 & France (Crépy en Valois) & Pork & Local & 16 sick and 1 dead & (Martel et al., 1906) \\
\hline 1900 & Spain & Pork & Local & 31 sick and 13 dead & (Martel et al., 1906) \\
\hline 1902-1903 & Czechoslovakia & Pork & Local & 34 sick and 5 dead & (Martel et al., 1906) \\
\hline $1930-1950$ & United States of America & Pork & United States of America & $\begin{array}{l}800 \text { sick and many } \\
\text { dead* }\end{array}$ & (Campbell,1983) \\
\hline 1945 & Ireland & Pork & Local & 705 sick & (Soulé et al., 1991) \\
\hline $1946-1967$ & Belarus & $\begin{array}{l}\text { Pork and some wild } \\
\text { animals }\end{array}$ & Local & 9,600 sick & (Bessonov, 1972) \\
\hline 1960 & Poland & Pork & Local & 1,122 sick & (Soulé et al., 1991) \\
\hline $1974-1995$ & France and Italy & Horse meat & $\begin{array}{l}\text { Eastern Europe and the } \\
\text { United States of America }\end{array}$ & $\begin{array}{l}3,000 \text { sick and } \\
5 \text { dead }\end{array}$ & $\begin{array}{l}\text { (Touratier et al., } \\
\text { 1999) }\end{array}$ \\
\hline
\end{tabular}

* In 1947, Gould noted that, out of 900 inhabitants over the age of 50 years who died and were autopsied in the State of Michigan, 234 were infested with the parasite T. spiralis and the author concluded that the United States of America was three times more heavily affected by this parasitosis than other countries (Campbell,1983).

Table I. - Main cases of human trichinellosis reported since the 19th century

explorers in 1897 can be attributed to the consumption of polar bear meat, the carcasses of which were found in their food stores, and Arvy believes that parasite infestation of this species already existed in the 18th century in this region (Campbell, 1983).

\section{IN HUMANS}

Many cases, the extent of which varies between countries and periods, have been described in the medical literature. These are summarised in Table I.

\section{SURVEILLANCE SYSTEMS}

W hen the role of pigs in the trichinellosis cycle was definitively established in the 1860 s, it became imperative to monitor the development of the disease in both animals and humans.

Moreover, trichinellosis surveillance has often been imposed on exporting countries by importing countries. Where this condition was not satisfied, the importing countries totally (or partially) prohibited importation. This was the case for American pork, which was prohibited in Greece, Italy and Portugal (1879), Germany, Spain (1880), Denmark (1888), Austria, France, Hungary, Turkey and Romania (1889), etc. (Campbell, 1983).

\section{HUMAN TRICHINELLOSIS}

In humans, it is essential to recognise parasitic infestation ante mortem if one wishes to attempt a treatment and to monitor the development of an epidemic.
Post mortem diagnoses are of less interest, except for epidemiologists.

In 1861, Küchenmeister recommended searching for the larvae by biopsy of the deltoid muscle using a trocar with a hook at the end, and Schaan recommended this method again in 1872 in his thesis entitled "A study of trichinosis" (Thèves, 1995).

Friedereich made the first diagnosis of trichinellosis in a living human being in 1862 , by means of a biopsy of the biceps muscle. In 1896, Brown proposed a diagnostic method in suspected cases: counting the number of polymorph eosinophil leucocytes (Soulé et al., 1991).

Other methods (titration of muscular enzymes, serum modifications, searching for specific antibodies) were not used until later, with the drawback of not being totally specific or giving belated results (Soulé et al., 1991).

\section{ANIMAL TRICHINELLOSIS}

Up until the discovery of immuno-diagnosis methods, parasite infestation was most frequently diagnosed post mortem, by trichinoscopy, in other words, by examining selected muscular fragments squeezed between two plates of glass under the microscope.

This method was used for the first time in the Duchy of Brunswick, in Germany, in 1863, and the number of pig carcasses subjected to such examination constantly rose each year (27,000 in 1895). This surveillance system employed more than 100,000 persons in 1899. An American mission, led by C.W. Stiles, criticised this "bureaucracy" which, according to him, was costing 3,275,000 dollars a year and did not detect all contaminated carcasses (Cassedy, 1971). 
In France, the first surveillance system was inaugurated, for meat imported from America, by the decree of 4 December 1891 (Martel et al., 1906).

In Denmark, trichinoscopic examination was set up in 1903 (Martel et al., 1906).

In the United States of America, trichinoscopic examination was only implemented on exported meat in 1891 following complaints from importing countries. Delayed due to its costs (seemed to be too high), trichinoscopic examination rapidly became more sophisticated than that of the Europeans thanks to improvements in the microscopes used and the training of the personnel responsible for such examinations (Cassedy, 1971).

\section{CONCLUSION}

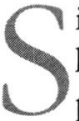
ince trichinellosis was discovered, this parasitosis has become a delicate issue, both for those responsible for public health and animal health and those in the production and trading of animal products. As Neumann wrote more than a century ago on the subject of American meat infected with trichina imported into Europe, in words that remain highly topical, whether concerning trichinellosis or other zoonotic diseases: "This question of (American) meat has given rise to frequent and lively debates in the press and in learned and other societies. This is because it affects many interests: those of trade that demand free importation; those of agriculture, that rejoice in the probibition, and those of consumers, some of whom want free entry which would lower the price of meat, and others that demand measures to protect public bealth" (Neumann, 1892) Such discussions are very likely to continue for some time because, like all zoonoses, this parasitosis evolves over time. The conditions of infestation of the various animal species and mankind can change very rapidly in step with changes in the environment, climatic upheavals, the use of new foodstuffs (for animals and humans), the growth in international trade, etc.

Trichinellosis surveillance will, therefore, become even more difficult, and it can safely be said that its history is far from over...

\section{REFERENCES}

Bessonov A.S. Epizootiology (epidemiology) and prophylaxis of trichinellosis. Mintis Ed. Vilnius, 1972, 302 pp. (in Russian).

Blancou J. Histoire de la surveillance et du contrôle des maladies animales transmissibles. Office international des épizooties, Paris, 2000, 301-320.

Brumpt E. Précis de parasitologie. Sixième édition. Masson et $\mathrm{C}^{\mathrm{ie}}$, Paris, 1949, $1042 \mathrm{pp}$.
Campbell W.C. History of trichinosis: Paget, Owen and the discovery of Trichinella spiralis. Bull. Hist. Med., 1979, 53, 520-552

Campbell W.C. Historical introduction, in 'Trichinella and Trichinosis'. Plenum Press. NY and London, 1983, 258 pp.

Cassedy J.H. Applied Microscopy and American Pork Diplomacy: Charles Wardell Stiles in Germany. Isis, 1971, 62, 5-20.

Martel H., de Loverdo J. \& Mallet A. Les abattoirs publics. Vol. II : Inspection et administration des abattoirs. Installation des marchés aux bestiaux. Dunod et Pinot Édit., Paris, 1906, 646 pp.

Neumann L.G. Traité des maladies parasitaires non microbiennes des animaux domestiques. Seconde édition. Asselin et Houzeau Édit, Paris, 1892, 768 pp.

Soulé C., Dupouy-Camet J., Ancelle T., Bourée P. \& TouraTIER L. La trichinellose : une zoonose en évolution. OIE/ CNEVA Éd., Paris, 1991, 292 pp.

ThÈves G. Helminthologie vétérinaire, Ann. Méd. vét., 1995 , 139, 241-248.

Touratier L., Boireau P., Dupouy-Camet J. \& Pages J.-P. La trichinellose du cheval et son importance en santé publique vétérinaire. Faits et conséquences. Bull. Soc. Vét. Prat. de France, 1999, 83 (4), 223-263. 